\title{
Mineralogy of dumortierite-bearing abyssal pegmatites at Starkoč and Běstvina, Kutná Hora Crystalline Complex
}

\author{
Mineralogie abysálních pegmatitů s dumortieritem \\ ze Starkoče a Běstviny, Kutnohorské krystalinikum
}

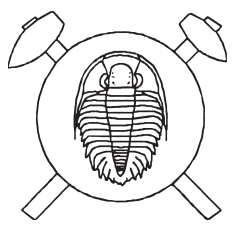

(8 figs, 3 tabs)

\author{
JAN CEMPÍREK ${ }^{1,2}-$ MILAN NOVÁK $^{2}$ \\ ${ }^{1}$ Department of Mineralogy and Petrography, Moravian Museum, Zelný trh 6, CZ-659 37 Brno \\ ${ }^{2}$ Institute of Geological Sciences, Masaryk University, Kotlárská 2, CZ-611 37 Brno
}

\begin{abstract}
Abyssal pegmatites from Starkoč and Běstvina are typical examples of the AB-BBe subclass pegmatites in the Bohemian Massif. The features typical for origin and evolution of both abyssal pegmatites are better preserved in the pegmatite at Starkoč, where, based on paragenetic relationships, three distinct assemblages were recognized: (i) Primary igneous assemblage: plagioclase I + quartz I + muscovite + garnet III + tourmaline I + dumortierite I + chrysoberyl; (ii) Prograde metamorphic assemblage: quartz II + plagioclase II + kyanite + $\mathrm{K}$-feldspar + staurolite + tourmaline II + dumortierite II; (iii) Retrograde metamorphic assemblage: pyrophyllite and kaolinite. Plagioclase, quartz and muscovite are major minerals in the pegmatite veinlet; the most common accessory minerals include tourmaline, dumortierite, garnet, K-feldspar and kyanite, whereas only trace amounts of chrysoberyl, staurolite and several very rare accessory minerals were found. Composition of tourmaline is controlled by the two-stage evolution of the pegmatite. Primary tourmaline I from Starkoč exhibits crystallization trend expressed by the substitution $\left({ }^{\mathrm{Y}, \mathrm{Z}} \mathrm{Al}^{\mathrm{T}} \mathrm{Al}\right)\left({ }_{\mathrm{Y}, \mathrm{Z}} \mathrm{R}^{2+} \mathrm{S}^{4+}\right)$. Prograde metamorphic event introduced additional $\mathrm{Fe}$ and $\mathrm{Mg}$ from the host rock into the system and remobilization of B allowed crystallization of Mg-enriched, rather homogeneous tourmaline II. Strakoč and all other known pegmatites of AB-BBe subclass in the Bohemian Massif occur in the Gföhl Unit, along the easternmost border of the Moldanubicum. Pegmatite host rocks exhibit HP metamorphic conditions and low degree of MP overprint. Such metamorphic evolution is a typical feature of host rocks of similar abyssal pegmatites in high-grade terrains in Antarctica, Norway and Madagascar.
\end{abstract}

Key words: abyssal pegmatite; dumortierite; tourmaline; Kutná Hora Crystalline Complex

\section{Introduction}

Abyssal (metamorphic) pegmatites are related to anatectic processes in high-grade metamorphic rocks of upper amphibolite to granulite facies. Their mineral assemblages are mostly simple, including common rock-forming minerals such as muscovite, biotite, garnet, tourmaline, cordierite and $\mathrm{Al}_{2} \mathrm{SiO}_{5}$ modifications besides major minerals - quartz, plagioclase and/or K-feldspar. Abyssal pegmatites form dikes, lenses or irregular bodies commonly about several $\mathrm{cm}$ to several $\mathrm{dm}$ thick, hosted largely in metapelitic rocks. Their internal structure is commonly simple, complexly zoned pegmatites are rare. Based on the accessory minerals, the abyssal pegmatites were subdivided on four subclasses - AB-HREE, ABLREE, AB-U and AB-BBe (Černý - Ercit 2005).

Abyssal pegmatites of the AB-BBe subclass were described from several localities in high-grade metamorphic terranes e.g., in Antarctica (Grew 1981, 1998, Grew et al. 1998a, b, 2000), Madagascar (Grew et al. 1998b), Sri Lanka (Grew et al. 1995), India (Soman 1986), Norway (Huijismans et al. 1982), Zambia (Žáček - Vrána 2002) and Austria (Ertl et al. 1997, Kalt et al. 2001). They are characterized by the presence of B-rich and/or Be-bearing minerals such as Al-rich tourmalines, dumortierite, grandidierite, prismatine, boralsilite, werdingite, chrysoberyl, sapphirine, taaffeite and musgravite (redefined as ferrotaaffeite-6N'3S and magnesiotaaffeite-6N'3S; Armbruster 2002) (Grew 1996, 2002). Chrysoberyl is the most abundant Be-carrier in the abyssal pegmatites whereas beryl, typical in other classes of granitic pegmatites, is mostly absent. Compared to their magmatic relatives, abyssal pegmatites including AB-BBe subclass have been less commonly object of mineralogical and petrological studies (see e.g. Černý - Ercit 2005; Martin - De Vito 2005).

The pegmatite from Starkoč is a typical example of abyssal pegmatites of the AB-BBe subclass (cf. Černý Ercit 2005) along with several other localities in the Bohemian Massif (Fig. 1, Table 1; see e.g. Fiala 1954, Losert 1956, Čech 1985, Cempírek 2003, Cempírek Novák 2004a, b, Fuchs et al. 2005, Cempírek et al. 2006). It is located in high-grade metamorphic rocks of the Gföhl Unit, Kutná Hora Crystalline Complex. Here we present description of mineral assemblages, chemical composition of minerals, potential substitution mechanisms particularly in tourmaline and dumortierite from Starkoč and closely related abyssal pegmatite at Běstvina. The studied localities are compared to other occurrences of the abyssal pegmatites of the AB-BBe subclass in the Gföhl Unit, Moldanubian Zone, and with similar localities worldwide.

\section{General geology and occurrence}

Three distinct subunits were distinguished in the Kutná Hora Crystalline Complex on the basis of their lithology and metamorphic evolution: Micaschist Zone, Kouřim Nappe and Gföhl Unit, which is subdivided to the Běstvina Formation, Malín Formation and Plaňany Formation (Synek - Olivierová 1993). Metamorphic rocks of the Gföhl Unit underwent three-stage metamorphism and 
deformation (Synek - Olivierová 1993): (i) HP/HT metamorphic event $\mathrm{D}_{1}$ at $\mathrm{P} \sim 16-24 \mathrm{kbar}$ and $\mathrm{T} \sim 850-950^{\circ} \mathrm{C}$ (Vrána et al. 2005, Nahodilová et al. 2005) documented by abundant relics of granulitic fabrics; (ii) an amphibolite facies shear regime $D_{2}$ (Synek - Olivierová 1993) at $\mathrm{P} \sim 9$ kbar, $\mathrm{T} \sim 750{ }^{\circ} \mathrm{C}$ (Nahodilová et al. 2005); (iii) late reactivation event $\mathrm{D}_{3}$, which affected all previous fabrics and which is probably associated with the overthrusting of the Malín Formation over both the Micaschist Zone and the Kouřim Nappe (Synek - Olivierová 1993, Kachlík 1999). Partial anatexis is expected at high PT conditions of kyanite zone but the conditions have not been specified in detail so far (Nahodilová et al. 2005). Vrána et al. (2005) gave $\mathrm{T} \sim 670{ }^{\circ} \mathrm{C}$ and $\mathrm{P} \sim$ $14 \mathrm{kbar}$ for migmatitic gneiss. Anatexis producing kyanite-bearing leucosome was assumed to follow the event $\mathrm{D}_{2}$ (Synek - Olivierová 1993).

Metamorphic rocks of Malín and Běstvina Formations are locally crosscut by pegmatite bodies. Two distinct textural types of pegmatites were recognized: (i) Discordant pegmatite veinlets, commonly $1-3 \mathrm{~cm}$ thick, locally containing tourmaline and dumortierite as typical accessory minerals, as well as less abundant apatite, garnet, arsenopyrite, graphite and kyanite. They occur at localities Kutná Hora-Turkaňk, Starkoč, Běstvina and Spačice (Fiala 1954, Losert 1956, Čech 1985, Cempírek 2003). (ii) Simply zoned pegmatite bodies, up to $0.5 \mathrm{~m}$ thick, with very similar mineral assemblages to the type (i), including dumortierite and Al-rich tourmalines. These pegmatites are known only from the Malín Formation, at localities Miskovice and Kuklík near Kutná Hora (Fiala 1954, Losert 1956, Cempírek 2003, Cempírek et al. 2006). These zoned bodies show a slightly higher degree of fractionation and textural differentiation (Cempírek Novák 2004b). Accessory dumortierite and tourmaline were also found in leucocratic metapelites in this region (Losert 1956, Synek - Olivierová 1993). These rocks, however, do not exhibit such a high degree of melt segregation and transport like the pegmatites examined, which exhibit apparent intrusive character.

Starkoč, a famous mineralogical locality of almandine garnet studied by several authors (see e.g., Macháček
- Slavík 1960), is situated about $8 \mathrm{~km}$ ENE of Č́slav, in the Malín Formation (Fig. 1). Cretaceous sediments cover this area to a large extent and metamorphic rocks are exposed in few isolated windows. Discordant pegmatite veinlet, at least $10 \mathrm{~m}$ long with constant thickness of about $1-2 \mathrm{~cm}$ along the whole outcrop, cuts massive migmatized biotite gneiss. The veinlet is locally folded, generally WNW-trending and steeply dipping about $75^{\circ} \mathrm{SES}$, with sharp contact with the host rock. Muscovite flakes, up to $0.5 \mathrm{~cm}$ in size, are randomly distributed and near the contact locally deformed. Similar deformation features of muscovite were found along contact of metapegmatites in the Hrubý Jeseník Mts. (Novák et al. 2003).

Běstvina pegmatite is known only from several museum samples. As dumortierite was found at more than one locality in close vicinity of Běstvina (see review of Cempírek - Novák 2000), the precise position of the pegmatite locality is unknown; it is probably located in the neighbourhood of the road from Běstvina to Spačice. Generally, the veinlet is about $1 \mathrm{~cm}$ thick, crosscutting the host biotite gneiss.

Pegmatite veinlets of the AB-BBe subclass from the Gföhl Unit are very similar in their shape, size and mineral assemblages (Table 1). They are always hosted in high-grade rocks within the Gföhl Unit, particularly along the easternmost border of the Moldanubian Zone (Fig. 1). The Starkoč pegmatite represents the best developed and currently the best exposed locality of abyssal pegmatites in the Bohemian Massif.

\section{Methods}

Chemical composition of minerals was obtained using electron microprobe Cameca SX 100 at the Dionýz Štúr Institute of Geology, Bratislava. Analytical conditions: accelerating voltage $15 \mathrm{kV}$, beam current $20 \mathrm{nA}$; beam diameter 1-5 $\mu \mathrm{m}$. Following standards were used: $\mathrm{Na}$ - albite, $\mathrm{Ca}, \mathrm{Si}$ - wollastonite, $\mathrm{K}$ - orthoclase, $\mathrm{Mg}-\mathrm{MgO}, \mathrm{Fe}-\mathrm{Fe}_{2} \mathrm{O}_{3}, \mathrm{Cr}$ - chromite, $\mathrm{Mn}$ - rhodonite, $\mathrm{Al}-\mathrm{Al}_{2} \mathrm{O}_{3}, \mathrm{Ti}-\mathrm{TiO}_{2}, \mathrm{Cl}-\mathrm{NaCl}, \mathrm{F}-\mathrm{BaF}_{2}$. Data were reduced using the PAP routine (Pouchou - Pichoir 1985). The chemical formulae of tourmaline were

Table 1 Mineral assemblages of abyssal pegmatites from Gföhl unit. Data from Cempírek (2003) and Cempírek - Novák (2004).

\begin{tabular}{|c|c|c|c|}
\hline Pegmatite & Primary mineral assemblage & $\begin{array}{l}\text { Prograde metamorphic } \\
\text { mineral assemblage }\end{array}$ & $\begin{array}{l}\text { Retrograde metamorphic } \\
\text { mineral assemblage }\end{array}$ \\
\hline Starkoč & $\begin{array}{l}\mathrm{Plg}+\mathrm{Qtz}+\mathrm{Ms}+\mathrm{Grt}+ \\
\text { Tur I + Dum I + Cbr }\end{array}$ & $\begin{array}{l}\text { Qtz II }+ \text { Plg II }+ \text { Ky }+ \text { Kfs }+ \\
\text { Tur II }+ \text { Dum II }+ \text { St }\end{array}$ & pyrophyllite, kaolinite \\
\hline Běstvina & $\begin{array}{l}\text { Qtz I + Plg }+ \text { Ms }+ \\
\text { Dum I + Tur }\end{array}$ & $\begin{array}{l}\text { Qtz II + Dum II } \\
\pm \text { sillimanite (?) }\end{array}$ & fine-grained phyllosilicates \\
\hline Vémyslice & $\begin{array}{l}\text { Kfs }+ \text { Plg }+ \text { Qtz I }+ \\
\text { Bt }+ \text { Dum }\end{array}$ & Qtz II + sillimanite (?) & muscovite, fine-grained phyllosilicates \\
\hline Miskovice & $\begin{array}{l}\mathrm{Kfs}+\mathrm{Plg}+\mathrm{Qtz}+ \\
\mathrm{Ms} \mathrm{I}+\text { Tur }+ \text { Dum }\end{array}$ & Qtz + Dum II (?) & Ms II \\
\hline Kutná Hora - Kuklík & $\begin{array}{l}\text { Early: Plg }+ \text { Kfs }+ \text { Qtz }+ \text { Tur I } \\
\text { Late: Qtz }+\mathrm{Cb}+\text { Dum I }+ \\
\text { Tur II + arsenopyrite }\end{array}$ & Qtz + Dum II & Ms ( \pm symplesite $)$ \\
\hline
\end{tabular}




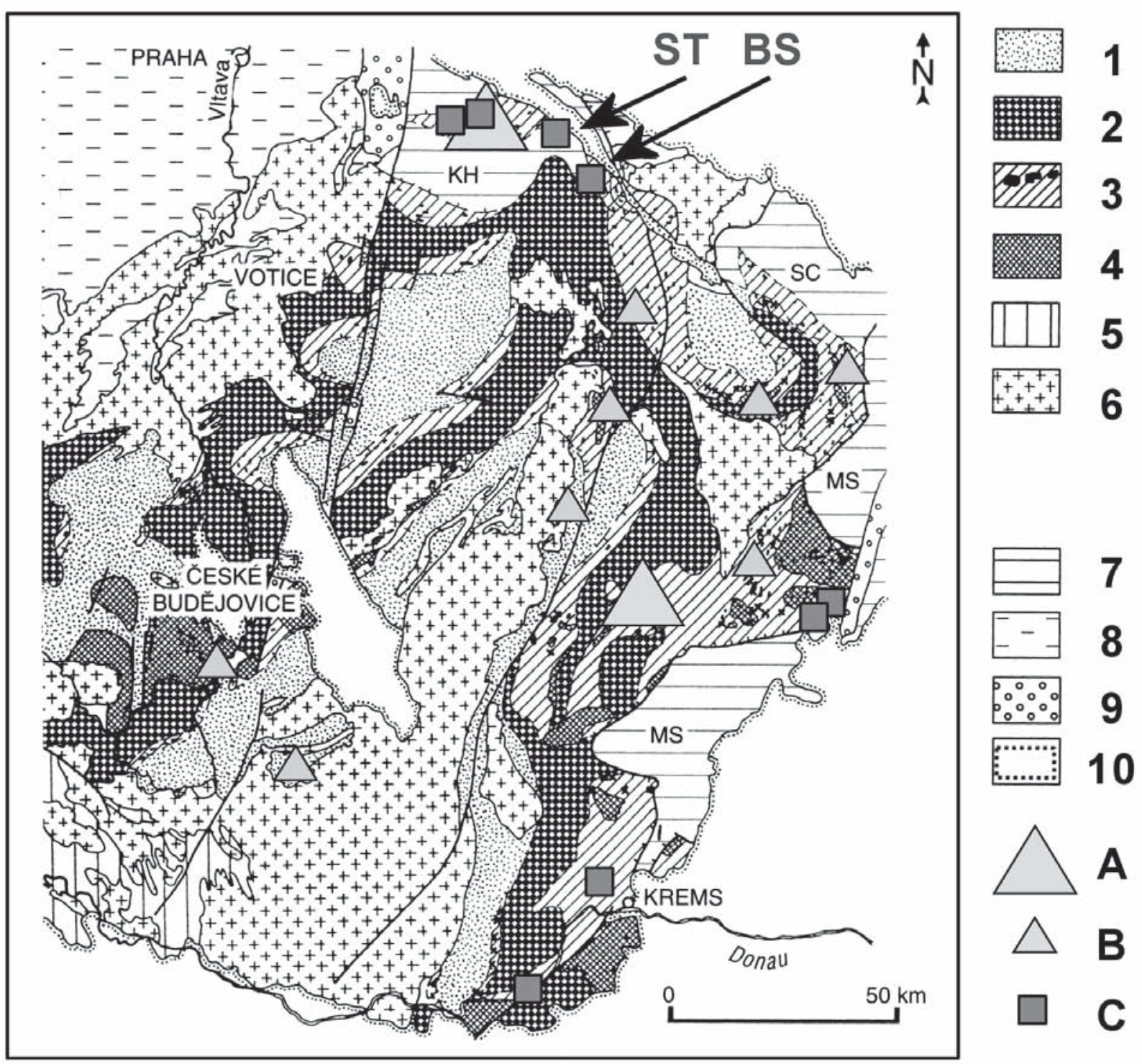

Fig. 1 Dumortierite occurrences in the Gföhl Unit in the Czech Republic and Austria, and position of studied localities Starkoč (ST) and Běstvina (BS). Map modified after Chlupáč et al. (2002), data from Cempírek - Novák (2000).

\section{Symbols:}

A - major occurrences in boron-bearing granulites and migmatites (localities in vicinity of Kutná Hora and Jemnice)

B - rare occurrences in granulites, migmatites and gneisses (from W to E: Plešovice, Malonty near Kaplice, Vanov, Jihlava, Pohled near Havl. Brod, Račice near Hrotovice, Horní Bory, Vojetín near Bystřice n. P.)

$\mathrm{C}$ - occurrences in abyssal pegmatites (from N to S: Kutná Hora - Kuklík, Miskovice, Starkoč, Běstvina, Vémyslice, Trstěnice, Gföhl, Klein Pochlarn)

Explanation of the map:

1 - Monotonous (Ostrong) series

2 - Varied (Drosendorf) series

3 - Gföhl Unit with ultrabasic bodies

4 - granulites of the Gföhl Unit

5 - Bavarian part of Moldanubicum

6 - granitoids

7 - crystalline units outside of Moldanubicum

8 - unmetamorphosed units outside of Moldanubicum

9 - limnic Permian cover

10 - outer contour of Mesozoic and younger sediments 
calculated on the basis of sites $\mathrm{T}+\mathrm{Z}+\mathrm{Y}=15$, assuming total $\mathrm{Fe}$ as $\mathrm{Fe}^{2+}, \mathrm{Li}=0$ and $\mathrm{OH}$ preferentially present in the V-site.

Cathodoluminescence study was done on instrument HC2-LM with technology of "hot" luminescence, equipped with SIMON - NEUSER microscope.

Whole-rock chemical analyses were performed at the Acmé Chemical Laboratories Ltd, Vancouver, Canada, by $\mathrm{ICP}$ - ES (major oxides, Ba, Ni, Sc, Mo, Cu, Pb, Zn, As, $\mathrm{Cd}, \mathrm{Sb}, \mathrm{Bi}, \mathrm{Ag})$ and ICP - MS (Co, Cs, Ga, Hf, Nb, Rb, Sn, Sr, Ta, Th, Tl, U, V, W, Zr, Y and REE).

\section{Petrography and bulk geochemistry of host rocks and pegmatites}

Massive biotite gneiss at Starkoč contains locally large porphyroblasts of garnet enclosed in felsic leucosome. The mineral assemblage of gneiss is: quartz + plagioclase + Ti-rich biotite $\left(\mathrm{X}_{\mathrm{Mg}} \sim 0.51-0.53\right)+$ garnet I $\left(\mathrm{Alm}_{71-}\right.$ $\left.{ }_{68} \operatorname{Prp}_{16-12} \mathrm{Sps}_{14-4} \mathrm{Grs}_{11-5}\right) \pm$ kyanite, the leucosome consists of a fine-grained assemblage: quartz + plagioclase $+\mathrm{K}$ feldspar with accessory apatite, dumortierite and tourmaline. Porphyroblasts of homogeneous violet-red garnet II (Alm ${ }_{77} \operatorname{Prp}_{16} \mathrm{Sps}_{5} \mathrm{Grs}_{2}$ ) commonly volumetrically predominate over the host leucosome. The mineral assemblages and textural relations suggest that the rock underwent several metamorphic and deformation events similar to the rocks in the Běstvina granulite (Vrána et al. 2005, Nahodilová et al. 2005). However, they were not studied in a greater detail at the Starkoč locality. At Běstvina, the precise location of the pegmatite is unknown; therefore petrography of the host rock could not be studied.

Chemical compositions of host massive biotite gneiss (leucosome portions not included) and pegmatite are given in Table 2. At Starkoč, the gneiss and pegmatite ex- hibit similar concentrations of $\mathrm{SiO}_{2}$ (71-73 wt.\%), $\mathrm{Al}_{2} \mathrm{O}_{3}$ (13-15 wt.\%), $\mathrm{CaO}$ (1.56-1.77 wt.\%) and $\mathrm{Na}_{2} \mathrm{O}(2.39-$ 3.05 wt.\%). They differ particularly in higher concentrations of $\mathrm{Fe}_{2} \mathrm{O}_{3}$ (5.45 versus $\left.1.57-1.58\right), \mathrm{MgO}$ (1.79 versus $0.20-0.35)$ and $\mathrm{TiO}_{2}(0.74$ versus $0.10-0.05)$ in host rock, and higher $\mathrm{K}_{2} \mathrm{O}(2.30-2.95$ versus 1.78$)$ in pegmatite (all in wt.\%). The pegmatite is enriched in As, Ba, $\mathrm{Ga}$ and $\mathrm{Sr}$, whereas host rock is apparently enriched in Cs, HFSE and REE. The chondrite-normalized REE patterns of host rocks and pegmatite are very similar disregarding higher concentrations of REE and a weak enrichment in HREE in metapelite (Fig. 2). Chemical compositions of host biotite gneisses at Starkoč and Běstvina including their REE patterns are very similar to felsic granulite type II, migmatite gneiss and granulitic gneiss in the Běstvina granulite body, respectively (Vrána et al. 2005).

\section{Petrography and mineralogy of the pegmatites}

\subsection{Starkoč pegmatite}

The mineral assemblages and textural relations indicate the presence of at least three individual stages in the Starkoč pegmatite evolution. (i) Primary igneous (magmatic) assemblage - plagioclase I + quartz + muscovite + tourmaline I + garnet III + dumortierite I \pm chrysoberyl is volumetrically dominant. (ii) Prograde metamorphic stage includes: a) newly-formed fine-grained assemblage of K-feldspar + kyanite + quartz replacing muscovite + plagioclase I, together with small amounts of staurolite; b) recrystallization of dumortierite I and tourmaline I producing new generations of dumortierite II and tourmaline II; c) corrosion of chrysoberyl; (iii) Retrograde metamorphic assemblage involves pyrophyllite and kaolinite, formed by replacement of muscovite and feldspars in

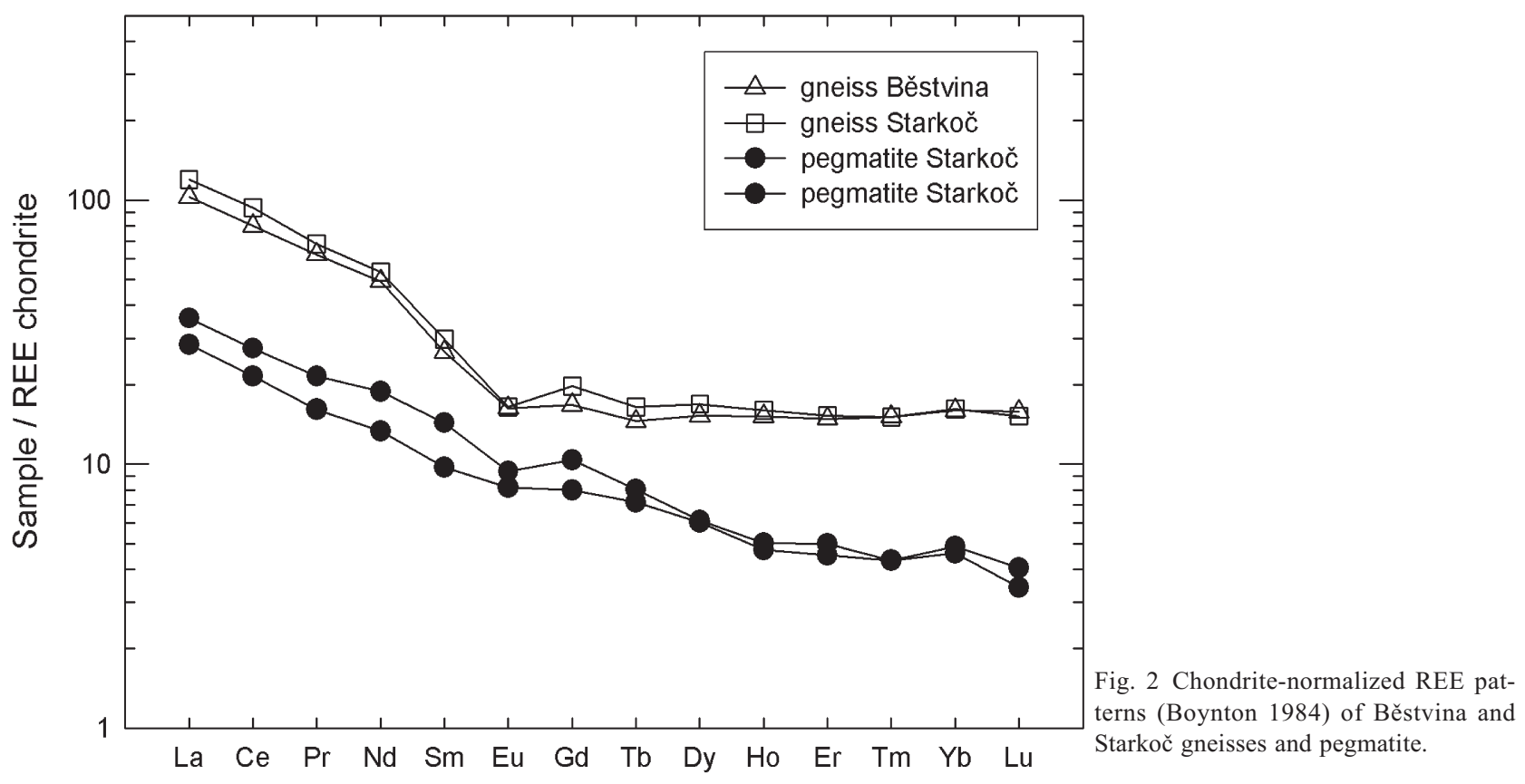


Table 2 Whole-rock analyses of the studied rock types.

\begin{tabular}{|c|c|c|c|c|}
\hline $\begin{array}{l}\text { locality } \\
\text { rock type }\end{array}$ & $\begin{array}{r}\text { Běstvina } \\
\text { gneiss }\end{array}$ & $\begin{array}{r}\text { Starkoč } \\
\text { gneiss }\end{array}$ & $\begin{array}{r}\text { Starkoč } \\
\text { pegmatite }\end{array}$ & $\begin{array}{r}\text { Starkoč } \\
\text { pegmatite }\end{array}$ \\
\hline \multicolumn{5}{|l|}{ [wt.\%] } \\
\hline $\begin{array}{l}\mathrm{SiO}_{2} \\
\mathrm{TiO}_{2} \\
\mathrm{Al}_{2} \mathrm{O}_{3} \\
\mathrm{Fe}_{2} \mathrm{O}_{3} \\
\mathrm{MnO} \\
\mathrm{MgO} \\
\mathrm{CaO} \\
\mathrm{Na}_{2} \mathrm{O} \\
\mathrm{K}_{2} \mathrm{O} \\
\mathrm{P}_{2} \mathrm{O}_{5} \\
\mathrm{LOI} \\
\mathrm{TOT} / \mathrm{C} \\
\text { total }\end{array}$ & $\begin{array}{r}55.36 \\
0.92 \\
21.13 \\
7.64 \\
0.09 \\
2.94 \\
0.70 \\
2.21 \\
5.07 \\
0.08 \\
2.90 \\
0.00 \\
99.04\end{array}$ & $\begin{array}{r}71.44 \\
0.74 \\
13.31 \\
5.45 \\
0.09 \\
1.79 \\
1.56 \\
2.81 \\
1.78 \\
0.11 \\
0.80 \\
0.04 \\
99.92\end{array}$ & $\begin{array}{r}72.93 \\
0.10 \\
14.93 \\
1.57 \\
0.02 \\
0.35 \\
1.72 \\
2.39 \\
2.92 \\
0.01 \\
2.80 \\
0.21 \\
99.95\end{array}$ & $\begin{array}{r}73.28 \\
0.05 \\
15.03 \\
1.59 \\
0.02 \\
0.20 \\
1.77 \\
3.05 \\
2.30 \\
0.03 \\
2.60 \\
0.16 \\
100.08\end{array}$ \\
\hline \multicolumn{5}{|l|}{ [ppm] } \\
\hline $\begin{array}{l}\text { As } \\
\text { Ba } \\
\text { Bi } \\
\text { Cd } \\
\text { Co } \\
\text { Cs } \\
\text { Cu } \\
\text { Ga } \\
\text { Hf } \\
\text { Mo } \\
\text { Nb } \\
\text { Ni } \\
\text { Pb } \\
\text { Rb } \\
\text { Sb } \\
\text { Sc } \\
\text { Sn } \\
\text { Sr } \\
\text { Ta } \\
\text { Th } \\
\text { Tl } \\
\text { U } \\
\text { V } \\
\text { W } \\
\text { Y } \\
\mathrm{Zn} \\
\mathrm{Zr}\end{array}$ & $\begin{array}{r}2.0 \\
760.0 \\
0.5 \\
0.3 \\
22.0 \\
9.5 \\
52.0 \\
30.0 \\
3.9 \\
1.0 \\
14.7 \\
70.0 \\
4.0 \\
249.0 \\
0.7 \\
20.0 \\
8.0 \\
126.0 \\
1.2 \\
12.3 \\
0.8 \\
3.5 \\
140.0 \\
1.0 \\
27.0 \\
133.0 \\
147.0\end{array}$ & $\begin{array}{r}2.0 \\
383.0 \\
0.5 \\
0.2 \\
11.3 \\
5.3 \\
10.0 \\
15.9 \\
6.3 \\
1.0 \\
11.3 \\
20.0 \\
3.0 \\
92.3 \\
0.5 \\
13.0 \\
4.0 \\
180.0 \\
0.9 \\
10.1 \\
0.3 \\
2.5 \\
69.0 \\
1.0 \\
29.7 \\
78.0 \\
246.0\end{array}$ & $\begin{array}{r}63.0 \\
1271.0 \\
1.0 \\
0.2 \\
2.0 \\
1.4 \\
9.0 \\
22.6 \\
0.8 \\
0.8 \\
6.2 \\
13.0 \\
2.0 \\
63.2 \\
0.7 \\
6.0 \\
3.0 \\
234.4 \\
0.5 \\
3.6 \\
0.1 \\
2.0 \\
11.0 \\
3.0 \\
11.2 \\
9.0 \\
16.7\end{array}$ & $\begin{array}{r}65.0 \\
927.0 \\
1.4 \\
0.2 \\
1.5 \\
1.4 \\
14.0 \\
21.3 \\
0.8 \\
1.0 \\
5.0 \\
16.0 \\
4.0 \\
49.3 \\
0.9 \\
3.0 \\
1.0 \\
290.2 \\
0.6 \\
5.5 \\
0.1 \\
3.3 \\
9.0 \\
3.0 \\
12.2 \\
5.0 \\
13.0\end{array}$ \\
\hline \multicolumn{5}{|l|}{ [ppm] } \\
\hline $\begin{array}{l}\text { La } \\
\text { Ce } \\
\text { Pr } \\
\text { Nd } \\
\text { Sm } \\
\text { Eu } \\
\text { Gd }\end{array}$ & $\begin{array}{r}31.90 \\
64.70 \\
7.60 \\
29.60 \\
5.20 \\
1.20 \\
4.34\end{array}$ & $\begin{array}{r}37.10 \\
75.90 \\
8.32 \\
32.00 \\
5.80 \\
1.21 \\
5.12\end{array}$ & $\begin{array}{r}8.80 \\
17.40 \\
1.97 \\
8.00 \\
1.90 \\
0.60 \\
2.07\end{array}$ & $\begin{array}{r}11.10 \\
22.20 \\
2.63 \\
11.30 \\
2.80 \\
0.69 \\
2.69\end{array}$ \\
\hline$\Sigma$ LREE & 144.54 & 165.45 & 40.74 & 53.41 \\
\hline $\begin{array}{l}\text { Tb } \\
\text { Dy } \\
\text { Ho } \\
\text { Er } \\
\text { Tm } \\
\text { Yb } \\
\text { Lu }\end{array}$ & $\begin{array}{l}0.69 \\
4.92 \\
1.09 \\
3.12 \\
0.49 \\
3.35 \\
0.51\end{array}$ & $\begin{array}{l}0.78 \\
5.45 \\
1.15 \\
3.21 \\
0.49 \\
3.39 \\
0.49\end{array}$ & $\begin{array}{l}0.34 \\
1.94 \\
0.34 \\
0.95 \\
0.14 \\
0.96 \\
0.11\end{array}$ & $\begin{array}{l}0.38 \\
1.98 \\
0.36 \\
1.05 \\
0.14 \\
1.02 \\
0.13\end{array}$ \\
\hline$\Sigma$ HREE & 14.17 & 14.96 & 4.78 & 5.06 \\
\hline$\Sigma$ REE & 158.71 & 180.41 & 45.52 & 58.47 \\
\hline
\end{tabular}

* all $\mathrm{Fe}$ as $\mathrm{Fe}_{2} \mathrm{O}_{3}$ pegmatite. Similar stages and mineral assemblages were found in most pegmatite veins from the Gföhl Unit (Table 1; see also Cempírek 2003, Cempírek - Novák 2004a), but chrysoberyl and staurolite are known only from Starkoč.

\subsubsection{Major minerals}

Plagioclase I forms subhedral to anhedral grains, with common polysynthetic twinning lamellae and undulose extinction in polarized-light microscope. Plagioclase I is locally rimmed by a thin zone of very fine-grained mixture of K-feldspar, kyanite, plagioclase II and quartz II in contact with muscovite. Plagioclase I and II have closely similar chemical composition $\left(\mathrm{Ab}_{78} \mathrm{An}_{19} \mathrm{Kfs}_{3}-\right.$ $\left.\mathrm{Ab}_{84} \mathrm{An}_{15} \mathrm{Kfs}_{1}\right)$. Kaolinization sometimes occurs along fractures in plagioclase.

Fine-grained anhedral quartz I fills space among grains of plagioclase I. It also encloses tourmaline I, dumortierite I, and garnet III. Quartz I is locally accumulated in the centre of the veinlet. Extremely fine-grained quartz II forms veinlets along interfaces of plagioclase I and quartz I. It contains small grains of kyanite, K-feldspar, muscovite, rare chrysoberyl and sometimes also dumortierite I, which is corroded and overgrown by needles and fibrous aggregates of dumortierite II. Muscovite forms subhedral flakes, up to $5 \mathrm{~mm}$ in size, randomly distributed within of the pegmatite veinlet. Undulose extinction and deformation are common. The fine-grained prograde metamorphic assemblage (ii) commonly rims large flakes of muscovite. Muscovite is locally replaced by pyrophyllite, commonly also in a close vicinity of the prograde assemblage.

\subsubsection{Common accessory minerals}

\section{Tourmaline}

Tourmaline occurs in two distinct types. Tourmaline I forms pleochroic ( $\mathrm{E}=$ colourless, $\mathrm{O}=$ light brown-green $)$ prismatic crystals, up to $2 \mathrm{~mm}$ in size, commonly broken and/or corroded. It is enclosed in quartz I and plagioclase I. Pleochroic tourmaline II (E = colourless, $\mathrm{O}=$ dark green) occurs as narrow rims along fractures or as microscopic spots within tourmaline I. It is typically associated with quartz II.

Tourmaline I and II have quite a wide compositional range (Table 3, Fig. 3). The T-site exhibits highly variable contents of Si (5.52 to 5.99 apfu). The T-site tends to be fully occupied by $\mathrm{Si}$ in tourmaline II, whereas in tourmaline I the T-site contains up to $0.48 \mathrm{apfu}{ }^{\mathrm{T}} \mathrm{Al}$. The $\mathrm{Z}$-site is assumed to be fully occupied by $\mathrm{Al}$, although a minor disorder of $\mathrm{Mg}$ between the $\mathrm{Y}$ - and $\mathrm{Z}$-sites can be expected. The $\mathrm{Y}$-site is highly variable in $\mathrm{Al}, \mathrm{Fe}$ and $\mathrm{Mg}$ (Fig. 3a). Composition of the tourmaline I shows vari- 
Table 3 Chemical composition of tourmaline and dumortierite from Starkoč and Běstvina.

\begin{tabular}{|c|c|c|c|c|c|c|c|c|c|c|}
\hline & \multicolumn{6}{|c|}{ Starkoč } & \multicolumn{4}{|c|}{ Běstvina } \\
\hline & Tur I & Tur I & Tur I & Tur II & Dum & Dum & Tur I & Tur II & Dum & Dum \\
\hline $\mathrm{SiO}_{2}$ & 35.58 & 34.56 & 33.20 & 35.24 & 31.14 & 31.29 & 35.97 & 35.86 & 31.79 & 30.47 \\
\hline $\mathrm{TiO}_{2}$ & 0.01 & 0.00 & 0.01 & 0.00 & 0.02 & 0.05 & 0.01 & 0.02 & 0.29 & 0.02 \\
\hline $\mathrm{Al}_{2} \mathrm{O}_{3}$ & 37.16 & 39.42 & 41.55 & 34.90 & 60.71 & 60.09 & 37.97 & 35.40 & 60.32 & 59.47 \\
\hline $\mathrm{B}_{2} \mathrm{O}_{3}{ }^{*}$ & 10.32 & 10.45 & 10.45 & 10.22 & 6.01 & 6.04 & 10.58 & 10.46 & 6.14 & 5.88 \\
\hline $\mathrm{Cr}_{2} \mathrm{O}_{3}$ & 0.00 & 0.02 & 0.00 & 0.00 & 0.00 & 0.00 & 0.06 & 0.04 & 0.00 & 0.00 \\
\hline MgO & 0.67 & 1.40 & 1.12 & 2.60 & 0.86 & 0.68 & 1.79 & 3.82 & 0.99 & 0.82 \\
\hline $\mathrm{CaO}$ & 0.16 & 0.42 & 0.61 & 0.40 & 0.00 & 0.02 & 0.19 & 0.29 & 0.02 & 0.02 \\
\hline MnO & 0.40 & 0.32 & 0.39 & 0.01 & 0.01 & 0.02 & 0.20 & 0.04 & 0.02 & 0.00 \\
\hline $\mathrm{FeO}$ & 9.97 & 8.15 & 7.23 & 9.45 & 0.28 & 0.34 & 9.16 & 8.26 & 0.25 & 0.29 \\
\hline $\mathrm{Na}_{2} \mathrm{O}$ & 1.50 & 1.64 & 1.66 & 1.63 & - & - & 1.62 & 1.83 & 0.03 & 0.01 \\
\hline $\mathrm{K}_{2} \mathrm{O}$ & 0.04 & 0.04 & 0.04 & 0.05 & - & - & 0.04 & 0.05 & 0.01 & 0.02 \\
\hline $\mathrm{H}_{2} \mathrm{O}^{*}$ & 2.71 & 2.77 & 2.76 & 2.88 & - & - & 2.94 & 3.00 & - & - \\
\hline $\mathbf{F}$ & 0.05 & 0.04 & 0.00 & 0.07 & - & - & 0.00 & 0.21 & 0.07 & 0.05 \\
\hline Cl & 0.02 & 0.01 & 0.00 & 0.01 & - & - & 0.00 & 0.00 & 0.01 & 0.00 \\
\hline $\mathrm{O}=\mathrm{F}$ & -0.02 & -0.02 & 0.00 & -0.03 & - & - & 0.00 & -0.09 & -0.03 & -0.02 \\
\hline $\mathrm{O}=\mathrm{Cl}$ & 0.00 & 0.00 & 0.00 & 0.00 & - & - & 0.00 & 0.00 & 0.00 & 0.00 \\
\hline total & 98.57 & 99.22 & 99.02 & 97.43 & 99.03 & 98.53 & 100.53 & 99.19 & 99.91 & 97.03 \\
\hline${ }^{\mathrm{T}} \mathbf{S i}$ & 5.993 & 5.747 & 5.520 & 5.996 & 3.000 & 3.000 & 5.911 & 5.959 & 3.000 & 3.000 \\
\hline${ }^{\mathrm{T}} \mathbf{A} \mathbf{l}$ & 0.007 & 0.253 & 0.480 & 0.004 & - & - & 0.089 & 0.041 & - & - \\
\hline B & 3.000 & 3.000 & 3.000 & 3.000 & 1.000 & 1.000 & - & - & 1.000 & 1.000 \\
\hline${ }^{\mathrm{z}_{A}}$ & 6.000 & 6.000 & 6.000 & 6.000 & - & - & 6.000 & 6.000 & - & - \\
\hline${ }^{\mathbf{y}} \mathbf{A l}$ & 1.369 & 1.472 & 1.661 & 0.994 & 6.893 & 6.790 & 1.265 & 0.892 & 6.709 & 6.901 \\
\hline${ }^{{ }^{\mathrm{Y}}} \mathbf{T i}$ & 0.001 & 0.000 & 0.001 & 0.000 & 0.001 & 0.004 & 0.001 & 0.002 & 0.021 & 0.001 \\
\hline${ }^{\mathrm{Y}} \mathrm{Cr}$ & 0.000 & 0.003 & 0.000 & 0.000 & 0.000 & 0.000 & 0.008 & 0.005 & 0.000 & 0.000 \\
\hline${ }^{\mathrm{Y}} \mathbf{F e}$ & 1.404 & 1.133 & 1.005 & 1.345 & 0.023 & 0.027 & 1.259 & 1.148 & 0.020 & 0.024 \\
\hline${ }^{\mathrm{Y}} \mathbf{M g}$ & 0.168 & 0.347 & 0.278 & 0.659 & 0.124 & 0.097 & 0.439 & 0.946 & 0.139 & 0.120 \\
\hline${ }^{\mathrm{Y}} \mathbf{M n}$ & 0.057 & 0.045 & 0.055 & 0.001 & 0.001 & 0.002 & 0.028 & 0.006 & 0.002 & 0.000 \\
\hline${ }^{\mathrm{x}} \mathbf{N a}$ & 0.490 & 0.529 & 0.535 & 0.538 & - & - & 0.516 & 0.590 & 0.005 & 0.002 \\
\hline${ }^{\mathrm{x}} \mathrm{Ca}$ & 0.029 & 0.075 & 0.109 & 0.073 & - & - & 0.033 & 0.052 & 0.002 & 0.002 \\
\hline${ }^{x_{K}}$ & 0.009 & 0.008 & 0.008 & 0.011 & - & - & 0.008 & 0.011 & 0.001 & 0.003 \\
\hline${ }^{x_{\text {vac. }}}$ & 0.472 & 0.388 & 0.348 & 0.378 & - & - & 0.443 & 0.347 & - & - \\
\hline${ }^{\mathrm{v}} \mathrm{OH}$ & 3.000 & 3.000 & 3.000 & 3.000 & - & - & 3.000 & 3.000 & - & - \\
\hline${ }^{\mathrm{w}} \mathrm{OH}$ & 0.046 & 0.068 & 0.056 & 0.274 & - & - & 0.222 & 0.326 & - & - \\
\hline${ }^{\mathrm{w}} \mathbf{F}$ & 0.027 & 0.021 & 0.000 & 0.038 & - & - & 0.000 & 0.110 & 0.021 & 0.016 \\
\hline${ }^{\mathrm{w}} \mathrm{Cl}$ & 0.006 & 0.003 & 0.000 & 0.003 & - & - & 0.000 & 0.000 & 0.002 & 0.000 \\
\hline${ }^{\mathrm{w}} \mathbf{O}$ & 0.921 & 0.908 & 0.944 & 0.685 & 17.990 & 17.820 & 0.778 & 0.564 & 17.759 & 17.995 \\
\hline
\end{tabular}

* $\mathrm{B}_{2} \mathrm{O}_{3}$ and $\mathrm{H}_{2} \mathrm{O}$ content calculated on the basis of ideal stoichiometry.

able ${ }^{\mathrm{Y}} \mathrm{Al}(0.47$ to 1.66 apfu) and $\mathrm{Fe}(0.74$ to 1.66 apfu) and only low amounts of $\mathrm{Mg}(0.06 \mathrm{apfu})$. On the other hand, metamorphic tourmaline II has uniform Fe and Al contents $(\mathrm{Fe} \sim 1.16-1.25$ apfu, $\mathrm{Al} \sim 0.89-0.74$ apfu; see Fig. 3a) and highly variable content of $\mathrm{Mg}(0.16$ to 0.99 $a p f u)$. The contents of $\mathrm{Mn}(\leq 0.08 \mathrm{apfu})$ and $\mathrm{Ti}(\leq 0.01$ apfu) are very low in both tourmaline types. The X-site is characterized by high vacancy ( 0.48 to $0.31 p f u)$ in both tourmaline I and II. This vacancy is slightly higher in tourmaline I; however, $\mathrm{Na}(0.59$ to 0.49 apfu) prevails in all cases (Fig. 3b). Only slightly elevated Ca contents $(\leq 0.11$ apfu $)$ were recorded. Both tourmaline I and II show low F content $(\leq 0.12$ apfu) and rather low calculated $\mathrm{OH}$ (3.49 to $2.79 \mathrm{apfu}$; Fig 3c). Although the partitioning of $\mathrm{OH}$ between $\mathrm{V}$ - and $\mathrm{W}$-sites is not precisely known, it is clear that tourmaline I shows a significant fraction of "oxy-tourmaline" end-member(s), whereas tourmaline II contains elevated $\mathrm{OH}$ in $\mathrm{X}$-site.

\section{Dumortierite}

Dumortierite I forms strongly pleochroic (X = bluish, colourless, Y, Z = pale blue to deep azure blue) subhedral prismatic crystals often twinned along 110 , or ag- 


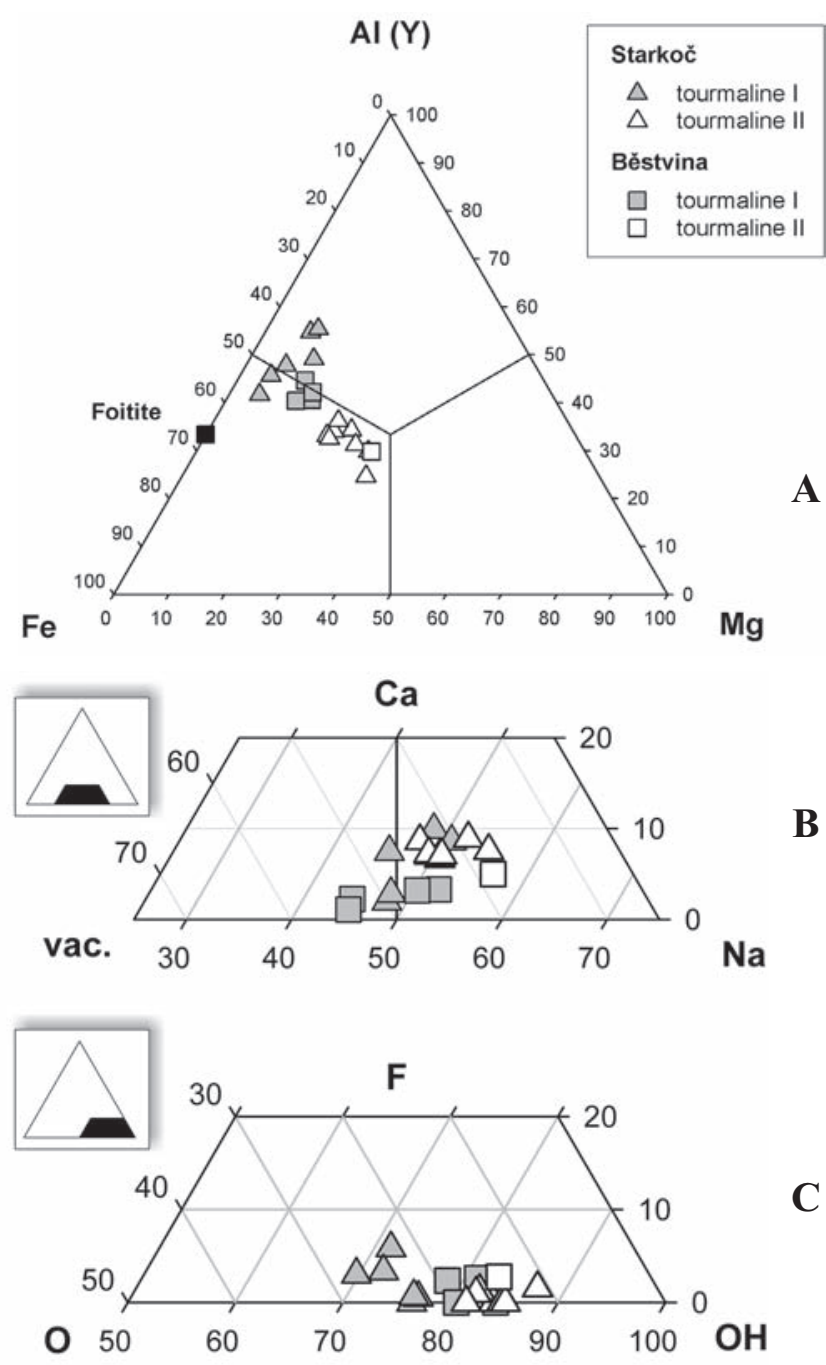

Fig. 3 Starkoč and Běstvina tourmaline composition. A - Y site, $\mathrm{B}-\mathrm{X}$ site, $\mathrm{C}-\mathrm{V}+\mathrm{W}$ sites. Analyses with prevailing oxy-tourmaline end-members exhibit $\mathrm{OH}<87.5$ in figure $3 \mathrm{C}$.

gregates of needle-like or fibrous crystals, up to $3 \mathrm{~mm}$ long, locally associated with tourmaline I. The crystals commonly exhibit features of shearing and recrystallization. Dumortierite II forms colourless, needle-like to fibrous aggregates enclosed in quartz II, overgrowing corroded grains of dumortierite I or rarely tourmaline I. Dumortierite has variable but low contents of $\mathrm{Mg}(0.05$ to 0.12 apfu), a uniform very low content of $\mathrm{Fe}(0.03$ apfu), and traces of $\mathrm{Ti}$. The $\mathrm{Al} / \mathrm{Si}$ ratio is rather low (Al $\sim 6.8$ at $\mathrm{Si}=3$ ). Dumortierite (Table 3 ) is expected to contain stoichiometric amount of B.

\section{Garnet}

Three morphologically and compositionally distinct types of garnet were recognized in gneiss and pegmatite at Starkoč. Small subhedral red to red-brown grains of garnet I $\left(\mathrm{Alm}_{71-68} \operatorname{Prp}_{16-12} \mathrm{Sps}_{14-4} \mathrm{Grs}_{11-5}\right)$, up to $1 \mathrm{~mm}$ in size, occur in fine-grained biotite gneiss matrix locally close to the contact with pegmatite veinlet. Large anhedral grains of violet-red garnet II, up to $10 \mathrm{~cm}$ in size, occur in fine-grained leucosome of migmatite. It is quite homogeneous; a bulk chemical analysis yielded composition corresponding to $\mathrm{Alm}_{77} \operatorname{Prp}_{16} \mathrm{Sps}_{5} \mathrm{Grs}_{2}$, the EMP study confirmed its homogeneity and found slightly increased $\mathrm{Mn}$ at rims. The FT-IR spectroscopy has proven that the garnet II does not contain any water, even at ppm level. Garnet II from Starkoč was the first recorded occurrence of water-free almandine garnet at all (Cempírek et al. 2003). Rare grains of subhedral orange-red garnet III $\left(\mathrm{Alm}_{80-62} \mathrm{Sps}_{30-10} \operatorname{Prp}_{8-3} \mathrm{Grs}_{3-2}\right)$, commonly less than $1 \mathrm{~mm}$ size, were found in pegmatite. Its composition varies in the individual grains and it is distinctly different from the former two types, being enriched in spessartine and depleted in pyrope and grossular components. Minute inclusions of monazite-(Ce), xenotime-(Y) and fluorapatite were found in garnet III.

\subsubsection{Other accessory and secondary minerals}

Chrysoberyl was found in a single grain about $0.1 \times 0.05$ $\mathrm{mm}$ in size, as strongly corroded crystal among grains of plagioclase II, K-feldspar and tourmaline I (Fig. 4). Although a patchy zoning of the grain is visible in the BSE image, no chemical differences between the individual zones were detected. WDA analysis yielded only $\mathrm{Al}_{2} \mathrm{O}_{3}$ and very low amounts of $\mathrm{SiO}_{2}$. The calculated sums of oxides are in good agreement with the theoretical formula $\mathrm{BeAl}_{2} \mathrm{O}_{4}$. The other two possible Al-rich minerals, gibbsite and diaspore, yielded much lower or higher calculated sum of oxides. This strongly supports the identity of chrysoberyl, which fits best to the WDA analyses. Kyanite occurs in fine-grained aggregates associated with quartz II, K-feldspar $\left(\mathrm{Kfs}_{95-88} \mathrm{Ab}_{5-12}\right)$, plagioclase II and rare staurolite (Figs 5 and 6). Minerals of this prograde metamorphic assemblage typically form irregular

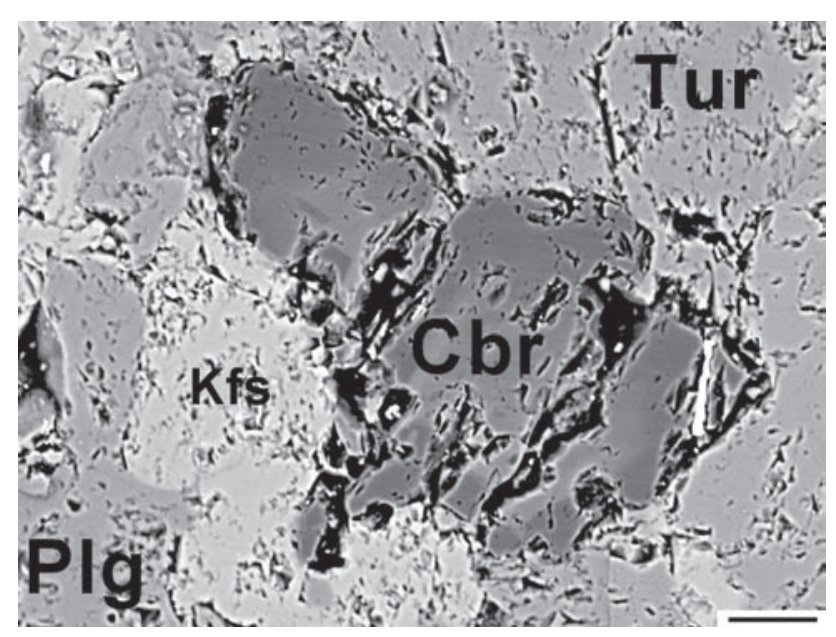

Fig. 4 Corroded grain of chrysoberyl, at the contact with tourmaline I, $\mathrm{K}$-feldspar and plagioclase II. Starkoč pegmatite. Scale bar is $20 \mu \mathrm{m}$. 


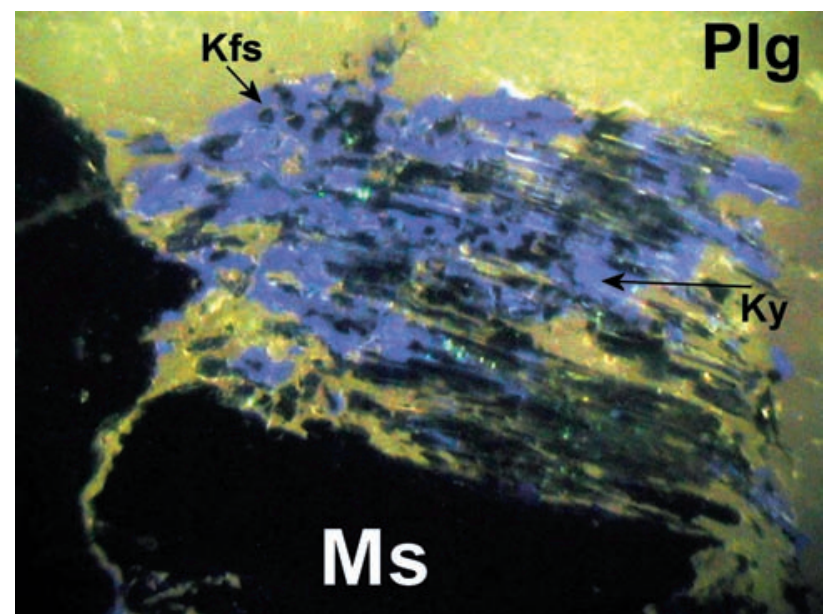

Fig. 5 CL-photograph of fine-grained aggregate of kyanite (light blue) + K-feldspar (blue) + quartz II (dark), within altered contact of muscovite crystal (black) with plagioclase II (yellow). Few grains of apatite (green) are present. Picture width is about $0.6 \mathrm{~mm}$.

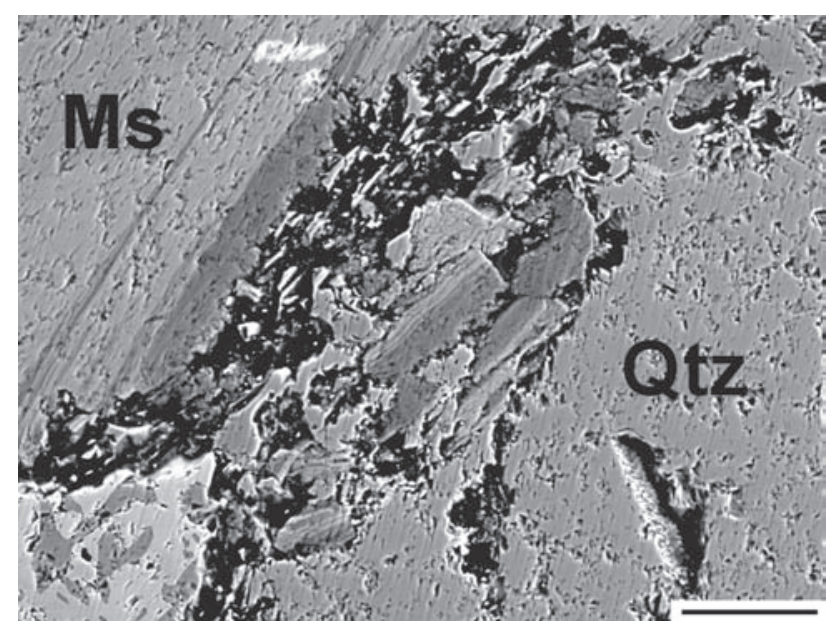

Fig. 6 Fine-grained aggregate of kyanite + quartz II + plagioclase II $+\mathrm{K}$-feldspar, within altered rim of muscovite crystal, at the contact with quartz I. Spotty light grain at the bottom left is staurolite with inclusions of quartz II. Darker rim of muscovite is formed by pyrophyllite. Scale bar is $50 \mu \mathrm{m}$.

grains less than $50 \mu \mathrm{m}$ in diameter, only staurolite was found as intergrowths with quartz in few grains up to $100 \mu \mathrm{m}$ in size. Staurolite is rather poor in $\mathrm{Mg}(0.32-0.38$ apfu) and rich in Fe (2.98-3.15 apfu) with variable contents of Si and Al (7.6-7.9 apfu Si, 18.5-18.0 apfu Al), concentrations of other elements are low. Rare accessory minerals include fluorapatite, monazite-(Ce) and xenotime-(Y) as rare inclusions in garnet III, and löllingite. They were not studied in detail.

\subsection{Běstvina pegmatite}

Pegmatite from Běstvina exhibits similar mineralogy and textural relations as Starkoč pegmatite (Table 1). The metamorphic overprint is less developed, which is indi- cated by the scarcity of the quartz II, tourmaline II and dumortierite II and by the absence of kyanite and staurolite. However, only several samples from this pegmatite are known which do not enable such a detailed characterization of the mineral assemblages comparing to Starkoč.

\subsubsection{Major minerals}

Anhedral grains of quartz I encloses crystals of plagioclase I, muscovite, tourmaline and dumortierite. Quartz is the prevailing mineral of the veinlet. Fine-grained quartz II is very rare; it forms thin veinlets, locally enclosing dumortierite I and II.

Plagioclase I $\left(\mathrm{Ab}_{82} \mathrm{An}_{15} \mathrm{Kfs}_{2}\right)$ forms subhedral to anhedral elongated grains and crystals, with common polysynthetic twinning lamellae. Its crystals are often oriented perpendicularly to the pegmatite border. Plagioclase is commonly slightly replaced by fine-grained phyllosilicates, rarely by dumortierite II.

Muscovite forms euhedral crystals, up to $10 \mathrm{~mm}$ in size, commonly oriented perpendicularly to the pegmatite border. Undulose extinction is common. Muscovite commonly encloses dumortierite I, locally also dumortierite II at the rims of muscovite crystals.

\subsubsection{Common accessory minerals}

Dumortierite from pegmatite at Běstvina is also represented by two generations. Primary dumortierite I strongly prevails over rare dumortierite II. Long-prismatic subhedral crystals of pleochroic dumortierite I $(X=$ yellowish, colourless, $\mathrm{Y}, \mathrm{Z}=$ pale bluish to deep azure blue) are mostly enclosed in muscovite, sometimes also in quartz. When enclosed in quartz, it commonly forms crystals twinned along 110. Fibrous pleochroic dumortierite II (pleochroic colours same as dumortierite I) is quite rare, it was found overgrowing the primary dumortierite I or in thin veinlets of fine-grained quartz II. The chemical composition of Běstvina dumortierite is very simple, besides rather stoichiometric Al and Si only low content of $\mathrm{Mg}$ (up to $0.15 \mathrm{apfu}$ ) and very low $\mathrm{Fe}$ and $\mathrm{Ti}$ (up to $0.05 \mathrm{apfu}$ ) were found (Table 3).

\subsubsection{Other accessory and secondary minerals}

Tourmaline from pegmatite at Běstvina was found in a single anhedral, strongly brecciaed grain. Chemical data indicate two generations of tourmaline, compositionally very similar to the Starkoč tourmaline (see Fig. 3). The amount of the prograde metamorphic tourmaline II in Běstvina seems to be very low and limited to thin fractures or zones within the primary tourmaline I.

Colourless fibrous sillimanite (?) was rarely observed together with the fibrous dumortierite II. Its identity was not proved by any analysis. 


\section{Discussion}

6.1. Compositional evolution and substitution mechanisms in tourmaline and dumortierite

Composition of tourmaline from abyssal pegmatites at Starkoč and Běstvina is controlled by their two-stage origin. Fractionation of $\mathrm{Fe}, \mathrm{Mn}, \mathrm{Mg}$ and $\mathrm{Al}$ in primary tourmaline $\mathrm{I}$ is of special interest. In tourmaline I from Starkoč the $(\mathrm{Fe}+\mathrm{Mn}) / \mathrm{Mg}$ ratio decreases with increasing $\mathrm{Al}_{\text {tot }}$, whereas in quite homogeneous tourmaline I from Běstvina this ratio is constant along with this increase (Fig. 7). Because the analytical points in Fig. 7 represent core-to-rim zonality in several crystals, the data can be regarded as a fractional crystallization of tourmaline I. Such a reversed fractionation as expressed by $(\mathrm{Fe}+\mathrm{Mn}) /$ $\mathrm{Mg}$ ratio in tourmaline I from Starkoč is unusual if compared to other tourmaline data from abyssal pegmatites in the Gföhl Unit (Fig 7; see also Cempírek 2003) and from granitic pegmatites worldwide. The compositional evolution of tourmaline from schorl-dravite-foitite to elbaite-rossmanite-olenite and an increase in $(\mathrm{Fe}+\mathrm{Mn}) / \mathrm{Mg}$ ratio are general geochemical trends found in most types of granitic pegmatites (see e.g. Selway et al. 1999, Novák 2000, Cempírek - Novák 2004b). The reason for the reversed fractionation trend in Starkoč tourmaline is unknown.

The prograde metamorphic event introduced additional $\mathrm{Fe}$ and $\mathrm{Mg}$ from the host rock into the system and remobilization of B allowed crystallization of tourmaline II.

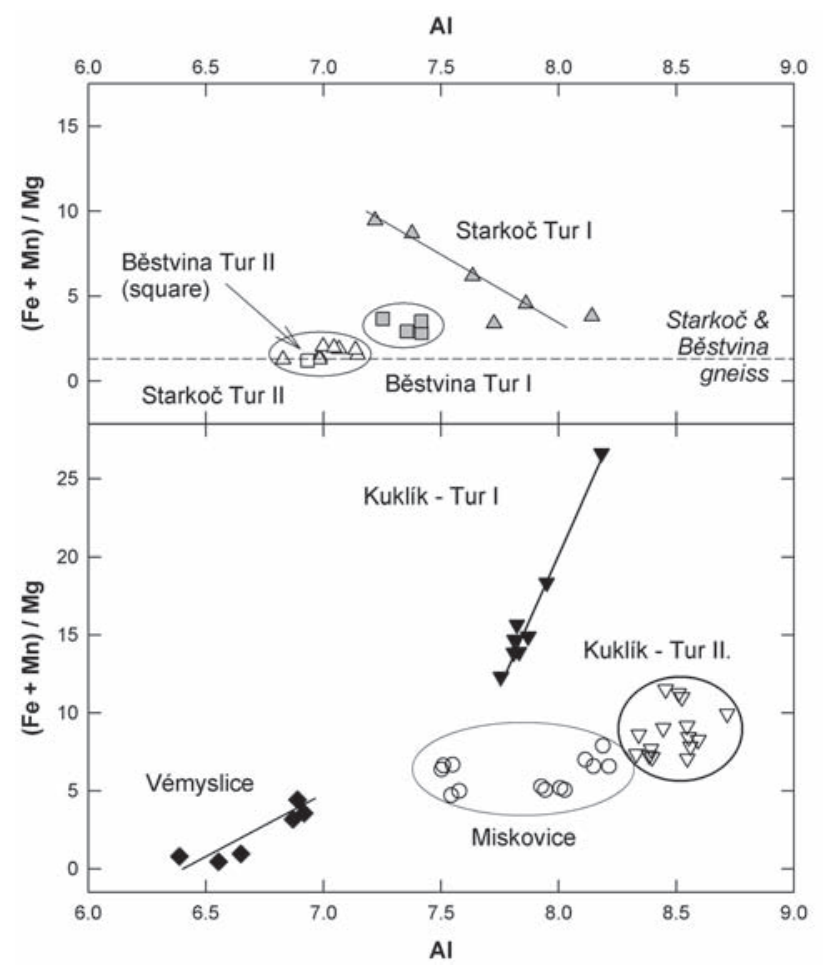

Fig. 7 Fractionation trends of $(\mathrm{Fe}+\mathrm{Mn}) / \mathrm{Mg}$ ratio versus total $\mathrm{Al}$ in tourmaline from abyssal pegmatites in the Gföhl unit. Horizontal line at $(\mathrm{Fe}+\mathrm{Mn}) / \mathrm{Mg}=1.6$ shows the value for host rock (gneiss) at Starkoč.
The "breakpoint" in evolution is visible in $(\mathrm{Fe}+\mathrm{Mn}) / \mathrm{Mg}$ ratio (Fig. 7), where sum of $\mathrm{Fe}+\mathrm{Mg}+\mathrm{Mn}$ increases via substitution for $\mathrm{Al}$ in both $\mathrm{Y}$ - and Z-sites. At both localities, the $(\mathrm{Fe}+\mathrm{Mn}) / \mathrm{Mg}$ ratio in secondary tourmaline II is very close to that in the host metamorphic rock (Fig. 7).

The primary tourmaline I is typical by its high Al-content and incorporation of $\mathrm{Al}$ into the $\mathrm{T}$-site, whereas the secondary tourmaline has rather stoichiometric Si content in T-site. The elevated content of Al in T-site is a typical feature of tourmaline from abyssal pegmatites (Cempírek 2003, Cempírek et al. 2006). Tourmaline I from Starkoč is Al-rich (up to 1.66 apfu in Y-site, up to 0.48 apfu in T-site), in Běstvina the content of ${ }^{\mathrm{T}} \mathrm{Al}$ is rather low (up to $0.2 \mathrm{apfu}$ ). Very high contents of Al (up to 2.2 apfu in Y-site, up to 0.52 apfu in T-site) were found in tourmaline at other localities of the region (Miskovice, Kuklík; Cempírek 2003, Cempírek et al. 2006), where $\mathrm{Al}_{2} \mathrm{SiO}_{5}$ minerals are absent. The deficiency of $\mathrm{Si}$ in the T-site might be also explained by the presence of ${ }^{\mathrm{T}} \mathrm{B}$ instead ${ }^{\mathrm{T}} \mathrm{Al}$. Although B was not analyzed, the authors do not expect significant amount of ${ }^{\mathrm{T}} \mathrm{B}$ due to moderate activity of $B$ in the system. It is well demonstrated by the presence of kyanite besides tourmaline and dumortierite. Primary tourmaline I from Starkoč and Běstvina with low variability in the $\mathrm{X}$-site exhibits crystallization trend expressed by substitution vector $\left({ }^{\mathrm{Y}, \mathrm{Z}} \mathrm{Al}{ }^{\mathrm{T}} \mathrm{Al}\right)\left(\mathrm{P}^{\mathrm{Y}, \mathrm{R}} \mathrm{R}^{2+}\right.$ $\left.{ }^{\mathrm{T}} \mathrm{Si}^{4+}\right)_{-1}$ or by combination of vectors $\left(\mathrm{Al}^{3+} \mathrm{OH}\right)\left(\mathrm{SiO}^{2-}\right)_{-1}$ and $\left(\mathrm{AlO}^{2-}\right)\left(\mathrm{R}^{2+} \mathrm{OH}\right)_{-1}$ in 1:1 ratio. Metamorphic tourmaline II is rather homogeneous and does not exhibit clear substitution trends (Fig. 8).

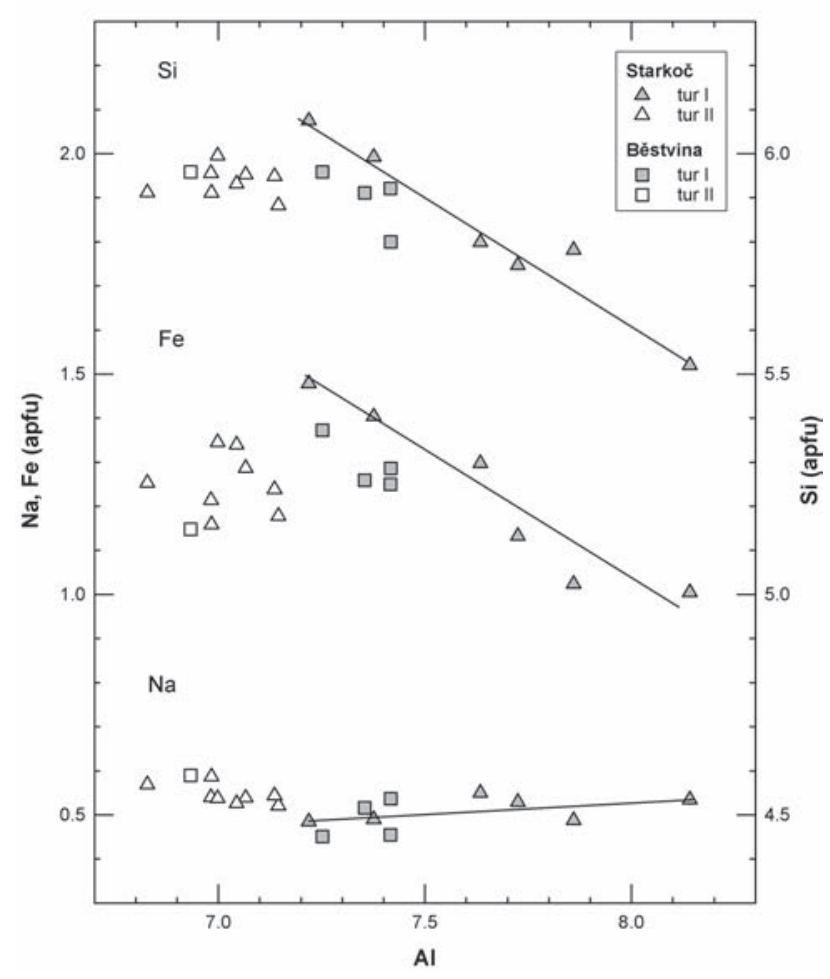

Fig. 8 Compositional trends of tourmaline from Starkoč and Běstvina. 
Dumortierite was found in two textural types. Primary dumortierite I forms prismatic crystals of blue to violet colour, up to $5 \mathrm{~mm}$ long, whereas dumortierite II forms fibrous aggregates of very light colour or colourless. Composition of primary dumortierite I is rather simple, with a very low contents of minor elements (Fe, $\mathrm{Mg}$, Ti). The very low colour intensity indicates that content of minor elements in fibrous dumortierite II is extremely low. Due to a very low amount of other analyzed elements than $\mathrm{Al}$ and $\mathrm{Si}$, it was not possible to chemically distinguish between the two textural generations of dumortierite, although textural and optical differences are apparent. At other localities (Kuklík and Miskovice near Kutná Hora; Fiala 1954, Losert 1956, Cempírek 2003), a similar dumortierite with light colour in shades of green was found. Very low Fe, Mg, Ti contents and smaller unit cell parameters are their typical features (unpublished data of JC).

Besides variation in minor elements, dumortierite has variable contents of the dominant elements and variable $\mathrm{Al} / \mathrm{Si}$ ratio (Table 3 ). This ratio is highly sensitive to analytical conditions but the variation in composition is seen even among analytical spots within the same analytical set. Water in dumortierite was not determined but only calculated on the basis of electrochemical neutrality. Variation in $\mathrm{Al} / \mathrm{Si}$ ratio can be explained by the substitution vectors $\square(\mathrm{OH})_{3}\left[\mathrm{AlO}_{3}\right]_{-1}$ and $\mathrm{Al}(\mathrm{OH})[\mathrm{SiO}]_{-1}$, which both incorporate $\mathrm{OH}$ into the structure of dumortierite. The former substitution seems to be most likely dominant.

\subsection{Comparison with other AB-BBe subclass pegmatites in the Moldanubian Zone}

The examined pegmatite veinlets from Starkoč and Běstvina exhibit typical paragenetic and textural features of abyssal pegmatites of the AB-BBe subclass (see e.g. Černý - Ercit 2005, Grew et al. 2000), such as the presence of Al-rich minerals, close relations to HP/HT metamorphic host rock, small thickness, elevated content of light elements (B, Be), and polyphase evolution. The discordant pegmatite veinlets from Vémyslice and Trstěnice near Moravský Krumlov are the only mineralogically similar localities known in the Bohemian Massif. These abyssal pegmatites exhibit thin veinlets, polyphase evolution, sharp contact with host rock and abundant dumortierite. In the case of Vémyslice locality the principal differences from the studied pegmatites include high bulk $\mathrm{K}_{2} \mathrm{O}$ content, abundant $\mathrm{K}$-feldspar but only secondary muscovite, presence of biotite and metamorphic sillimanite and elevated As in dumortierite (Cempírek - Novák 2004). The presence of sillimanite and biotite in Vémyslice instead of Al-rich tourmaline may suggest lower activity of B relative to Starkoč. Associated younger abyssal pegmatite veinlets containing oscillatory zoned tourmaline with moderate amounts of Al, graphic tourmaline + quartz intergrowths and andalusite are likely related to some LP event. Information about other abys- sal pegmatites with dumortierite from the Austrian part of the Moldanubian Zone (Miesling, Gföhl, Klein Pochlarn) is scarce; hence detailed comparison is not possible.

Simply zoned abyssal pegmatites from Kuklík and Miskovice exhibit a different internal structure, but their mineralogy is similar to the pegmatite veinlets at Běstvina and Starkoč. The main differences exist in internal structure showing the zoned development, a larger thickness of pegmatite bodies, transitional contacts, presence of enclaves of host rocks, and less apparent metamorphic overprint. A significant interaction with xenoliths suggests higher contents of volatiles, including $\mathrm{B}$, in the zoned abyssal pegmatites. It is also supported by a higher degree of fractionation, which is indicated by tourmaline composition (Fig. 7), and also by dumortierite composition, including late green dumortierite extremely poor in minor cations (Fe, $\mathrm{Mg}, \mathrm{Ti}$ ).

Disregarding the largely textural differences observed in the discordant pegmatite veinlets (Starkoč, Běstvina, Vémyslice) and the simply zoned abyssal pegmatites (Kuklík, Miskovice), they exhibit many similar features, namely almost identical mineral assemblages including accessory minerals. It suggests that they originated at similar PTX-conditions and that they are closely related to similar geological events.

\subsection{Comparison with other AB-BBe subclass pegmatites from the world localities}

Gay and Galliski (1979) reported from Virorco, San Luis, Argentina, mineral assemblages most similar to those described from abyssal pegmatites at Starkoč and Běstvina. At Virorco, two distinct types of pegmatites crosscut gabbros and norites within terrane formed by granulites and quartzites. The first one forms fine-grained veinlets, about $2-3 \mathrm{~cm}$ thick, with quartz, blue and green dumortierite, two types of tourmaline (black to blue and green to colourless), kyanite, plagioclase $\mathrm{An}_{10}$, muscovite, apatite, sillimanite and staurolite. The second pegmatite type forms coarser grained $(2.5-0.5 \mathrm{~cm})$ veins, up to 10 $\mathrm{cm}$ thick, consisting of quartz, plagioclase $\left(\mathrm{Ab}_{92-88} \mathrm{An}_{8-}\right.$ ${ }_{12}$ ), pinkish muscovite, black tourmaline, garnet, staurolite, chrysoberyl and blue dumortierite. Dumortierite occurs only in central parts of veins rich in quartz, whereas staurolite was found only in nodules with garnet or kyanite. Prismatic dumortierite I is commonly overgrown by fibrous dumortierite II and forms aggregates with quartz, muscovite and tourmaline. It is also locally replaced by kyanite and tourmaline. Two generations of dumortierite from Virorco pegmatites exhibit features very similar to those from Starkoč and Běstvina pegmatites. The presence of staurolite, kyanite, two generations of dumortierite and tourmaline replacement by other minerals suggests a polyphase evolution of the Virorco pegmatites.

Almgjotheii pegmatite, Norway, represents another abyssal pegmatite similar to Starkoč (Huijsmans et al. 1982, Grew et al. 1998a, b). It is located in garnetifer- 
ous migmatite and originated during their anatexis at $550-700^{\circ} \mathrm{C}$ and $3-5 \mathrm{kbar}$. Besides primary (magmatic) assemblage involving the following accessory minerals (dumortierite, andalusite, sillimanite, grandidierite, garnet), two prograde stages and one retrograde metamorphic stage were recognized. The prograde events produced werdingite, boralsilite, dumortierite II, sillimanite, grandidierite II, tourmaline, corundum, hercynite and andalusite II, all by the reaction of primary minerals with metamorphic fluids. Retrograde metamorphic phase is represented by sericite, chlorite and margarite (Grew et al. 1998b).

Thin veinlets of dumortierite-bearing pegmatites similar to Starkoč also are known from the Saxony Granulite Complex at the locality Hartmansdorf quarry (Vollstädt - Weiss 1991, Anderson et al. 1998). However, mineralogy of these pegmatites was not studied in a greater detail.

\section{Conclusions}

All known pegmatites of AB-BBe subclass in the Bohemian Massif occur in the Gföhl Unit (Kutná Hora Crystalline Complex, Moravian Moldanubicum, Moldanubicum of Waldviertel in Lower Austria), apparently along the easternmost border of the Moldanubicum (Fig. 1). Where studied in detail (Běstvina Granulite, Kutná Hora Crystalline Complex), HP metamorphic conditions of about 18-24 kbars in the host rocks and rapid exhumation were revealed (Vrána et al. 2005). These host rocks also exhibit low degree of MP overprint and such metamorphic evolution is a typical feature of host rocks of abyssal pegmatites in the high-grade terrains of Antarctica and Madagascar (Grew 1998). The presence of kyanite in some pegmatite bodies and in migmatitic leucosome suggests HP conditions of melting (cf. Nahodilová et al. 2005), but not specified in detail. Moreover, kyanite in Starkoč is a product of prograde metamorphic overprint; hence this overprint preceded relatively HP conditions as well.

Geological position of abyssal pegmatites of the ABBBe subclass in the Moldanubian Zone, such as apparent HP conditions of their origin and their absence in the other parts of the Moldanubian Zone indicate quite specific conditions necessary for generation of this type of pegmatites. Unfortunately, the host rocks of abyssal pegmatites were studied in detail only in a part of the Kutná Hora Crystalline Complex (Vrána et al. 2005). Although the individual known localities of AB-BBe subtype pegmatites in the Gföhl Unit are distant from each other, we expect them to originate during rather similar metamorphic processes which significantly affected their host rocks. Future research is necessary to reveal relations between abyssal pegmatites examined and geological evolution of their host rock complexes, including metamorphic overprints. Because similar conditions were found in other metamorphic terrains containing abyssal pegmatite of the AB-BBe subclass (see e.g., Grew 1996, 1998), dumortierite-bearing abyssal pegmatites may become a good indicator of HP-metamorphic conditions with a weak MP overprint and of a rapid exhumation in high-grade metamorphic terrains.

Acknowledgements. The authors thank to the reviewers dr. Stanislav Vrána and prof. Wali S. Faryad for constructive comments that significantly improved the manuscript. This work was supported by the research projects MK00009486201 to JC and MSM 21622412 to MN.

Submitted November 13, 2006

\section{References}

Anderson, A. J. - Mayanovic, R. A. - Bajt, S. (1998): A micro-XAFS study of aqueous chlorozinc complexing up to $430{ }^{\circ} \mathrm{C}$ in saline fluid inclusions from the Knaumühle granitic pegmatite, Saxonian Granulite Massif, Germany. - Canadian Mineralogist 36, 511-524.

Armbruster, T. (2002): Revised nomenclature of högbomite, nigerite, and taaffeite minerals. - Eur. J. Mineral. 14, 389-395.

Boynton, W. V. (1984): Cosmochemistry of the rare earth elements: meteorite studies. - In: Henderson P. (ed): Rare Earth Element Geochemistry. Elsevier, Amsterdam, p. 63-114.

Cempirek, J. (2003): Mineral assemblages and chemistry of dumortierite from granitic pegmatites. - MS thesis. Institute of Geological sciences, Masaryk University, Brno. 81 pages. (in Czech with English abstract)

Cempírek, J. - Buriánek, D. - Beran, A. - Novák, M. (2003): Locality no. 9: Starkoč near Čáslav. Garnet-biotite gneiss to migmatite, abyssal barren pegmatite. Minerals of interest: garnet $(\mathrm{OH})$, oxy-schorl, olenite (B,F,OH), dumortierite (B,OH). - In: (Novák, M. ed.): International symposium on light elements in rock forming minerals LERM 2003, Nové Město na Moravě, June 2003, Field trip guidebook, 71-76.

Cempirek, J. - Novák, M. (2000): Krystalochemie Al-bohatých borosilikátů. - Bull. mineral.-petrolog. Odd. Nár. Muz. (Praha), 8, 91-99. (in Czech)

- (2004a): Dumortierit a turmalín z abysálních pegmatitů od Vémyslic u Moravského Krumlova, gfohlská jednotka, moldanubikum. - Acta Musei Moraviae, Sci. Geol., 89, 1, 45-54. (in Czech with English abstract)

- (2004b): Abyssal pegmatite with olenite and dumortierite from Kutná Hora, Czech Republic: an example of fractionation in the Li-poor, Al, B-rich granitic system. - In: GAC-MAC 2004, St. Catharines, Ontario, Canada. Book of Abstracts 29, 225.

Cempírek, J. - Novák, M. - Ertl, A. - Hughes, J. M. - Rossman, G. R. Dyar, M. D. (2006): Fe-bearing olenite with tetrahedrally coordinated Al from an abyssal pegmatite at Kutná Hora, Czech Republic: structure, crystal chemistry, optical and XANES spectra. - Canadian Mineralogist 44, 1, 23-30.

Čech, F. (1985): Mineralogie žulových pegmatitů české části Českého masívu. - MS disertation thesis, Faculty of Science, Charles University, Praha. 333 pages. (in Czech)

Černý, P. - Ercit, T. S. (2005): The classification of granitic pegmatites revisited. - Canadian Mineralogist 43, 2005-2026.

Chlupáč, I. - Brzobohatý, R. - Kovanda, J. - Stráník, Z. (2002): Geological past of the Czech Republic. - Academia, Praha. 436 p. (in Czech)

Ertl, A. - Pertlik, F. - Brandstätter, F. (1997): Investigations on olenite with excess boron from the Koralpe, Styria, Austria. - Österr. Akad. Wiss. Math. - Naturw. K1. Anzeiger Abt. I, 134, 3-10.

Fiala, F. (1954): Dumortierite from Miskovice. - Sbor. Nár. Mus. Praha, 10B, 2, 3-38. (in Czech, with english, russian and german abstract)

Fuchs, Y. - Ertl, A. - Hughes, J. M. - Prowatke, S. - Brandtsätter, F. Schuster, R. (2005): Dumortierite from the Gföhl unit, Lower Austria: chemistry, structure, and infra-red spectroscopy. - Eur. J. Mineral. 17, 173-183. 
Gay, H. D. - Galliski, M. A. (1979): Dumortierita, crisoberilo y minerales asociados de Virorco, San Luis. - Actas Del Congreso Geologico Argentino. 7, Tomo II, 327-335.

Grew, E. S. (1981): Surinamite, taafeite, and berylian sapphirine from pegmates in granulte-facies rocks of Casey Bay, Enderby Land, Antarctica. - American Mineralogist, 66, 1022-1033.

Grew, E. S. (1996): Borosilicates (exclusive of tourmaline) and boron in rock-forming minerals in metamorphic enviroments. - In: Grew E. S. - Anovitz L. M. [ed.]: Boron. Mineralogy, petrology, and geochemistry. - Reviews in Mineralogy 33, 1996.

- (1998): Boron and beryllium minerals in granulite-facies pegmatites and implications of beryllium pegmatites for origin and evolution of the archean Napier complex of east Antarctica. - Memoirs of National Institute of Polar Research, Special Issue 53, 74-92. Tokyo.

- (2002): Beryllium in Metamorphic Environments (Emphasis on Aluminous Compositions). - In: Grew, E. S. [ed.]: Beryllium: Mineralogy, Petrology and Geochemistry. - Reviews in Mineralogy, 50, 487-549.

Grew, E. S. - Hiroi, Y. - Motoyoshi, Y. - Kondo, Y. - Jayatileke, S. J. M. Marquez, N. (1995): Iron-rich kornerupine in sheared pegmatite from the Wanni Complex, at Homagama, Sri Lanka. - Eur. J. Mineral. 7, 623-636.

Grew, E. S. - McGee, J. J. - Yates, M. G. - Peacor, D. R. - Rouse, R. C. Huijsmans, J. P. P. - Shearer, C. K. - Wiedenbeck, M. - Thost, D. E. Su, S.-C. (1998a): Boralsilite $\left(\mathrm{Al}_{16} \mathrm{~B}_{6} \mathrm{Si}_{2} \mathrm{O}_{37}\right)$ : A new mineral related to sillimanite from pegmatites in granulite-facies rocks. - American Mineralogist 83, 638-651.

Grew, E. S. - Yates, M. G. - Huijsmans, J. P. P. - McGee, J. J. - Shearer, C. K. - Wiedenbeck, M. - Rouse, R. C. (1998b): Werdingite, a borosilicate new to granitic pegmatites. - Canadian Mineralogist 36, 399-414.

Grew, E. S. - Yates, M. G. - Barbier, J. - Shearer, C. K. - Sheraton, J. W. Shiraishi, K. - Motoyoshi, Y. (2000): Granulite-facies beryllium pegmatites in the Napier Complex in Khmara and Amundsen bays, western Enderby Land, East Antarctica. - Polar Geoscience 13, 1-40.

Huijsmans, J. P. P. - Barton, M. - van Bergen, M. J. (1982): A pegmatite containing Fe-rich grandidierite, Ti-rich dumortierite and tourmaline from the Precambrian, high-grade metamorphic complex of Rogaland, S. W. Norway. - Neues Jahrb. Mineral., Abh. 143, 249-261.

Hughes, J. M. - Ertl, A. - Dyar, M. D. - Grew, E. S. - Shearer, C. K. Yates, M. G. - Guidotti, C. V. (2000): Tetrahedrally coordinated boron in a tourmaline: boron-rich olenite from Stoffhütte, Korlape, Styria. - Canadian Mineralogist 38, 861-868.

Kachlik, V. (1999): Relationship between Moldanubicum, the Kutná Hora crystalline unit and Bohemicum (Central Bohemia, Czech Republic): A result of polyphase Variscan nappe tectonics. - Journ. Czech Geol. Soc., 44, 201-291.

Kalt, A. - Schreyer, W. - Ludwig, T. - Prowatke, S. - Bernhardt, H.-J. Ertl, A. (2001): Complete solid solution between magnesian schorl and lithian excess-boron olenite in a pegmatite from Koralpe (eastern Alps, Austria). - Eur. J. Mineral. 13, 1191-1205.

Losert, J. (1956): Dumortierity z pegmatitů a migmatitů v širším okolí Kutné Hory. - Rozpr. ČSAV, 66, 1, 1-44. (in Czech with English abstract)

Macháček, V. - Slavik, J. (1960): Study of garnet for using in petrgraphy with the focus on sedimentary rocks. - Sbor. Ústř. Ústav geol., 26, 175-226. (in Czech)

Martin, R. F. - De Vito, C. (2005): The pattern of enrichment in felsic pegmatites ultimately depend on tectonic setting. - Canadian Mineralogist 43, 2027-2048.

Nahodilová, R. - Faryad, S. W. - Pertoldová, J. - Konopásek, J. - Štědrá, $V$. (2005): HP Melting and its Relationship to the Granulite Facies Metamorphism - an Example of the "Gföhl Nappe" in the Kutná Hora Crystalline Complex. - Geolines 19, 86-87.

Novák, M. (2000): Compositional pathways of tourmaline evolution during primary (magmatic) crystallization in complex (Li) pegmatites of the Moldanubicum, Czech Republic. Mem. Soc. Italiana Scienze Nat. Mus. Civ. Storia Nat, Milano, 30, 45-56.

Novák, M. - Černý, P. - Uher, P. (2003): Extreme variation and apparent reversal of $\mathrm{Nb}$-Ta fractionation in columbite-group minerals from the Scheibengraben beryl-columbite pegmatite, Maršíkov, Czech Republic. - Eur. J. Miner., 15: 565-574.

Pouchou, J. L. - Pichoir, F. (1985): "PAP" procedure for improved quantitative microanalysis. - Microbeam Analysis 20, 104-105.

Schreyer, W. - Wodara, U. - Marler, B. - van Aken, P. A. - Seifert, F. Robert, J.-L. (2000): Synthetic tourmaline (olenite) with excess boron replacing silicon in the tetrahedral site. I. Synthesis conditions, chemical and spectroscopic evidence. - Eur. J. Mineral., 12, 3, 529-541.

Selway, J. B. - Novák, M. - Černý, P. - Hawthorne, F. C. (1999): Compositional evolution of tourmaline in lepidolite-subtype pegmatites. Eur. J. Mineral. 11, 560-584.

Soman, K. - Nair, N. G. K. - Druzhnin, A. V. (1986): Chrysoberyl pegmatites of South Kerala and their metallogenic implications. - J. Geol. Soc. India 27, 411-418.

Synek, J. - Oliveriová, D. (1993): Terrane character of the north-east margin of the Moldanubian zone: the Kutná Hora Crystaline Conplex, Bohemian Massif. - Geol. Rundsch., 82, 566-582.

Taylor, S. R. - McLennan, S. M. (1985): The Continental Crust: Its Composition and Evolution. - Blackwell, Oxford, 312p.

Vollstädt, H. - Weiss, S. (1991): Mineralfundstellen Sächsisches Erzgebirge. - Wiese Verlag, München, $127 \mathrm{p}$.

Vrána, S. - Štědrá, V. - Fišera, M. (2005): Petrology and geochemistry of the Běstvina granulite body metamorphosed at eclogite facies confitions, Bohemian massif. - Journ. Czech Geol. Soc., 50, 96-106.

Žáček, V. - Vrána, S. (2002): Iron-rich chrysoberyl from Kalanga Hill, Muyombe District, northeastern Zambia. - Neues Jahrb. Mineral., Monatsh., 529-540.

\section{Mineralogie abysálních pegmatitů s dumortieritem ze Starkoče a Běstviny, Kutnohorské krystalinikum}

Abysální pegmatity ze Starkoče a Běstviny jsou typickými zástupci podtř́idy AB-BBe abysálních pegmatitů v Českém masivu. Znaky typické pro jejich původ a vývoj jsou nejlépe zachovány v pegmatitu Starkoč, kde byly na základě paragenetických vztahů rozlišeny 3 asociace: (i) Primární magmatická asociace: plagioklas I + křemen I + muskovit + granát III + turmalín I + dumortierit I + chrysoberyl; (ii) Prográdní metamorfní asociace: křemen II + plagioklas II + kyanit + K-živec + staurolit + turmalín II + dumortierit II; (iii) Retrográdní metamorfní asociace: pyrofylit a kaolinit. Plagioklas, křemen a muskovit jsou hlavními minerály pegmatitové žilky; mezi časté akcesorie patří turmalín, dumortierit, granát, K-živec a kyanit, pouze velmi vzácně byl nalezen submikroskopický chrysoberyl, staurolit a několik dalších akcesorických minerálů. Složení turmalínu je silně ovlivněno dvoufázovým vývojem pegmatitu. Složení primárního turmalínu I na lokalitě Starkoč vykazuje trend blízký substituci $\left({ }^{\mathrm{Y}, \mathrm{Z}} \mathrm{Al}{ }^{\mathrm{T}} \mathrm{Al}\right)\left({ }^{\mathrm{Y}, \mathrm{Z}} \mathrm{R}^{2+}{ }^{\mathrm{T}} \mathrm{Si}^{4+}\right){ }_{-1}$. Pozdější prográdní metamorfní event dodal do systému Fe a Mg z okolní horniny a remobilizace bóru zapríčinila krystalizaci homogenního turmalínu, který je obohacen o Mg. Starkoč, Běstvina a všechny další známé abysální pegmatity podtřídy AB-BBe v Českém masivu se objevují v Gföhlské jednotce, podél východní hranice Moldanubika. Okolní horniny abysálních pegmatitů vykazují znaky HP metamorfózy se slabými projevy MP metamorfózy. Tento metamorfní vývoj je typickým znakem i pro horniny s podobnými abysálními pegmatity v Antarktidě, Norsku a na Madagaskaru. 